\title{
EVALUASI KEBIJAKAN PENGELOLAAN KAWASAN PANTAI UTARA KABUPATEN BEKASI DALAM PENINGKATAN KESEJAHTERAAN MASYARAKAT PESISIR
}

\author{
Danial Thaib \\ Dosen PNS Kopertis Wilayah III Dpk pada Sekolah Tinggi llmu Manajemen Kosgoro
}

\begin{abstract}
The objectives of this research are to (i) Evaluate the desired results in the policies concerning spatial planning in North Coast Special Area Bekasi; (ii) analyze the people's views in the framework of the implementation of policies concerning the plan space utilization patterns in the North Coast Special Area Bekasi; and (iii) analyze the positive impact on gross domestic product of policy implementation plan regarding the utilization of space, in the North Coast Special Area Bekasi. This research was conducted in Coastal Areas Bekasi which consists of three districts namely Babelan District, District Tarumajaya, and Muara Gembong District covering an area of 24615.06 ha. Analysis of the data has been obtained from field data collection activities. Examination of the data in this research done by triangulation technique which is based on sources and methods to confirm the interview data, observation, questionnaires and documents. This study concludes, as follow: 1) The authorities in order to prioritize the utilization and management of coastal development Bekasi in the industrial sector; 2) The private sector to give priority to the industrial sector increased employment, achieve optimization ofthe utilization of coastal areas; 3) Community considers that the main priority is the priohty use of the industry, except for the prevention of environmental degradation, conservation, cultural activities and cultural goals to prioritize transportation and tourism, 4) The view NGOs to prioritize the utilization ofthe industryas a major priority in orderto develop the coastal villages Bekasi, and 5) Banking holds to the phority use ofmost ofthe industrial sector. Third, the positive impact the implementation of policies conceming the utilization of space in North Coast Special Area Bekasi to increase gross domestic income can be viewed through the largest contribution to GDP formation Bekasi.
\end{abstract}

\section{PENDAHULUAN}

Potensi wilayah pesisir dan lautan di dareah-daerah menjadi penting dalam pengelolaan sumber daya alam perikanan dan kelautan di masa depan, mengingat luas wilayah laut Indonesia adalah $62 \%$ dari luas wilayah nasional. Potensi ini menempatkan sumberdaya pesisir dan lautan memiliki nilai ekonomis dan ekologi yang tinggi.

Pengembangan sumber daya alam pesisir Indonesia berpotensi untuk pemenuhan kebutuhan dan kesejahteraan masyarakat. Salah satu sektor yang menjadi harapan percepatan perbaikan ekonomi tersebut adalah sektor prikanan dan kelautan, yang diharapkan dapat menjadi anda- dalam pengembangan sumber daya alam pesisir di Indonesia. Potensi pembangunan yang terdapat di wilayah pesisir secara garis besar terdiri dari tiga kelompok, yakni: 1) sumberdaya dapat pulih (renewable resources), 2) sumber daya tak dapat pulih (non-renewable resources), dan 3) jasa-jasa lingkungan (environmental services). Potensi yang dihasilkan dari daerah ini pada tahun 1987 tercatat sebesar Rp 36,6 trilyun, atau sekitar $22 \%$ dari total produk domestik bruto (Dahuri, dkk., 2004:12).

Sejalan digulirkannya sistem desentralisasi pembangunar melalui UndangUndang Nomor: 32 Tahun 2004 tentang Pemerintah Daerah, dengan sendirinya telah mengakibatkan perubahan para- 
digma tentang pengelolaan sumber daya perikanan dan kelautan dari pusat ke daerah, dan menjadi tanggung jawab pemerintah daerah bersama jajarannya yang terkait beserta masyarakat setempat.

Pemanfaatan sumberdaya pesisir dan lautan oleh bangsa indonesia sebenarnya tetah dilakukan sejak berabad-abad lamanya, sebagai salah satu sumber bahan makanan utama, khususnya protein hewani. Sementara itu, kekayaan minyak bumi, gas alam dan mineral lainnya yang terdapat di wilayah ini telah dimanfaatkan untuk menunjang pembangunan ekonomi nasional sejak awal Pelita I. Pemanfaatan sumber daya pesisir dan lautan sudah selayaknya dikelola dengan baik dan optimal karena dapat menunjang pembangunan ekonomi nasional dalam rangka mengantarkan bangsa ini mencapai derajat kemakmuran, keadilan, dan kesejahteraan.

Wilayah pesisir dapat dilihat dari tiga aspek, yaitu: aspek ekologis, aspek administratif, dan aspek perencanaan. Pertama, aspek ekologis, wilayah pesisir adalah wilayah yang masih dipengaruhi oleh proses-proses kelautan, dimana ke arah laut mencakup wilayah yang masih dipengaruhi oleh prosesproses daratan seperti sedimentasi. Kedua, aspek administratif, wilayah pesisir adalah wiiayah yang secara administrasi pemerintahan mempunyai batas terluar sebelah hulu dari Kecamatan atau Kabupaten atau Kota yang mempunyai hulu, dan kearah laut sejauh 12 mil dari garis pantai untuk Provinsi atau 1/3 dari 12 mil untuk Kabupaten/Kota. Ketiga, aspek perencanaan, wilayah pesisir adalah wilayah perencanaan pengelolaan dan difokuskan pada penanganan isu yang akan ditangani secara bertanggung jawab
(Naskah Akademik Pengelolaan Wilayah Pesisir, 2000:. 2).

Pendekatan desentralisasi dalam pengelolaan sumberdaya pesisir secara terpa$\mathrm{du}$ (Integrated Coastal Zone Management) adalah dengan memberikan kewenangan penuh kepada pemerintah daerah untuk melakukan pengelolaan pada wilayah pesisir di daerahnya, melalui pengaturan dan pemilihan rencana dan kegiatan pengeloaan yang iebih khusus untuk kegiatan konservasi, ekonomi, dan dan kebutuhan-kebutuhan sosial masyarakat yang berperan dalam pengelolaan wilayah pesisirnya (Budiman, 2005:130).

Pengelolaan wilayah pesisir dan laut secara terpadu adalah pendekatan pengelolaan wilayah pesisir yang melibatkan dua atau lebih ekosistem, sumberdaya, dan kegiatan pemanfaatan (pembangunan) secara terpadu (integrated) guna mencapai pembangunan wilayah pesisir secara berkelanjutan (Dahuri, dkk., 2004:24). Dalam konteks ini, keterpaduan (integration) mengandung tiga dimensi: sektoral, bidang ilmu, dan keterkaitan ekologis. Keterpaduan secara sektoral berarti bahwa perlu ada koordinasi tugas, wewenang dan tanggung jawab antar sektor atau instansi pemerintah pada tingkat pemerintah tertentu (horizontal integration); dan antar tingkat pemerintahan dari mulai tingkat desa, kecamatan, kabupaten, propinsi, sampai tingkat pusat (vertical integration). Keterpaduan sudut pandang keilmuan mensyaratkan bahwa didalam pengelolaan wilayah pesisir hendaknya dilaksanakan atas dasar pendekatan interdisiplin ilmu (interdisciplinary approaches), yang melibatkan bidang ilmu ekonomi, ekologi, teknik, sosiologi, hukum dan lainnya yang relevan karena wilayah pesisir pada dasarnya terdiri 
dari sistem sosial dan sistem alam yang terjalin secara kompleks dan dinamis.

Pemerintah Kabupaten Bekasi dalam rangka melaksanakan pembangunan wilayah pesisir telah mengeluarkan Peraturan Daerah (Perda) Kabupaten Bekasi Nomor: 5 Tahun 2003 tentang Rencana Tata Ruang Kawasan Khusus Pantai Utara Kabupaten Bekasi Tahun 2003-2013. Perda tersebut sudah berjalan selama delapan tahun dan dua tahun kedepan sudah memasuki masa akhir berlakunya. Kondisi ini sangat tepat untuk melakukan evaluasi implementasi di lapangan untuk penyempurnaan Perda di masa mendatang.

Penelitian ini difokuskan pada Evaluasi Kebijakan Pengelolaan Kawasan Pantai Utara Kabupaten Bekasi dalam Peningkatan Kesejahteraan Masyarakat Pesisir pada aspek pemanfaatan ruang yakni Perda No. 5 Tahun 2003 tentang rencana tata ruang kawasan khusus Pantai Utara yang berkaitan dengan aspek "rencana pemanfaatan ruang kawasan khusus Pantai Utara Bekasi". rintah Kabupaten Bekasi dapat merumuskan kembali strategi pengelolaan dan pemanfaatan sumber daya pesisir yang mengintegrasikan pendekatan kelestarian untuk mencapai pertumbuhan ekonomi, 2) Hasil evaluasi ini dapat digunakan sebagai acuan untuk semua penyelenggara kebijakan dalam menyusun kebijakan operasional dan perencanaan peraturan daerah di masa yang akan datang.

\section{KAJIAN TEORETIK}

\section{Kebijakan Penataan Ruang}

Menurut Haddad dan Demisky (1994:4) kebijakan adalah suatu keputusan eksplisit atau implisit atau keputusan kelompok yang dapat menetapkan arah yang berguna menuntun keputusan akan datang, memprakarsai, mempertahankan atau memperlambat tindakan atau tuntunan pelaksanaan keputusan yang telah dibuat sebelumnya. Kebijakan dibedakan oleh ruang lingkup, kerumitan, lingkungan keputusan, rentang pilihan, dan kriteria keputusan. Secara skematis rentang tersebut dapat digambarkan sebagai berikut:

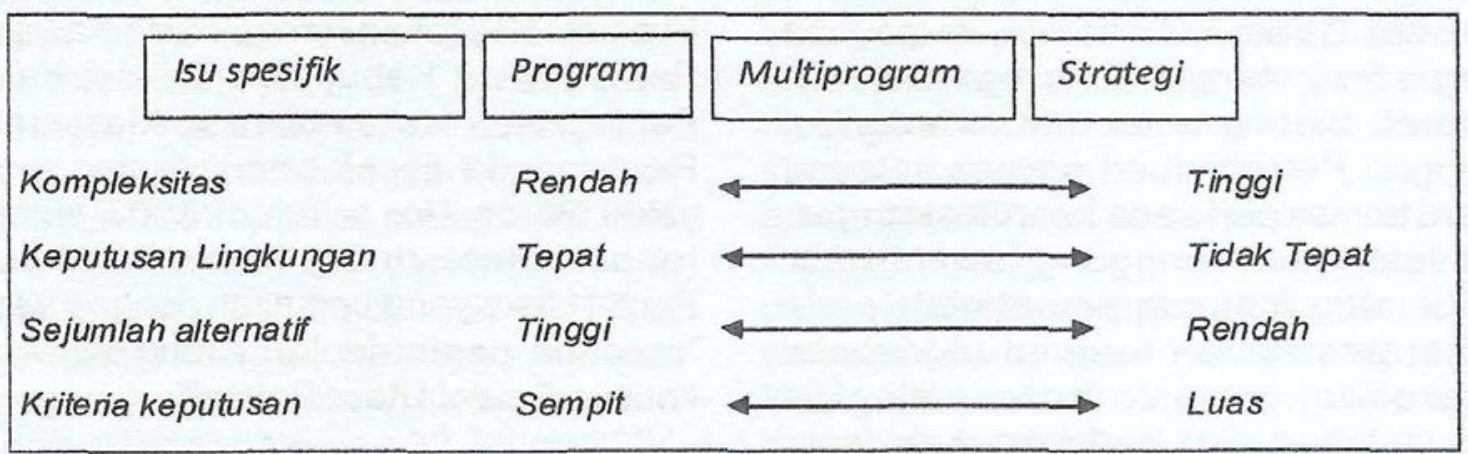

Gambar 1. Skema Rentang Kebijakan

Hasil penelitian ini diharapkan dapat digunakan dalam rangka memperoleh rekomendasi berkenaan dengan: 1) Evaluasi kebijakan pengelolaan wilayah pesisir dan hubungannya dengan kesejahteraan masyarakat agar Peme-
Suatu studi secara teoritik dan empiris oleh para ahli ilmu sosial menyatakan bahwa pembuatan kebijakan dicirikan oleh siapa aktor dan bagaimana proses pembuatan kebijakan. Pembuatan keputusan ini berfluktuasi dalam 
pendekatan sinoptis dan incremental (Haddad dan Demisky (1994: 5). Siklus pembuatan kebijakan secara umum dapat digambarkan pada bagan berikut:

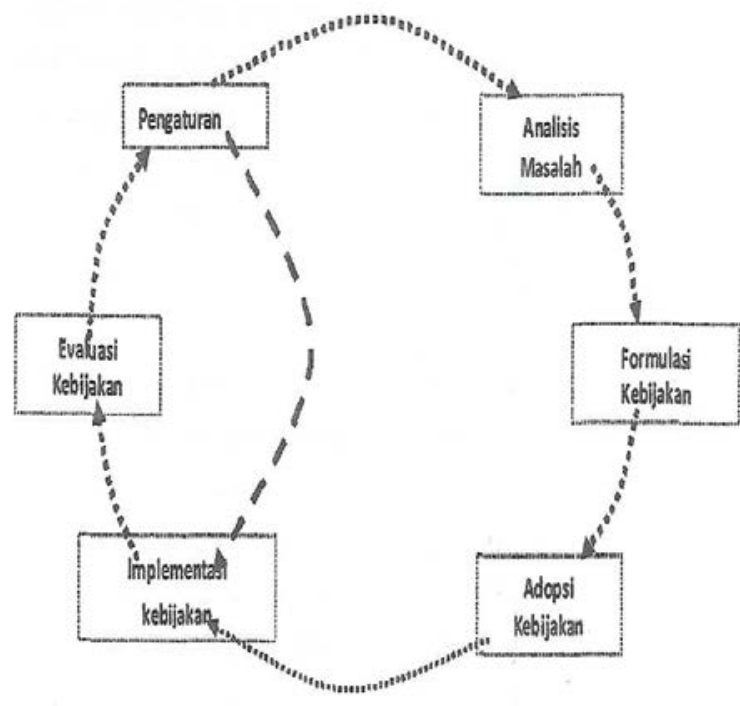

Gambar 2. Siklus Kebijakan

Aktor pembuat kebijakan dapat saja murni melakukan keputusan berdasarkan rasional yang ada, tetapi para pihak yang berkepentingan tidak menginginkan kebijakan sedemikian. Sehingga proses pembuatan kebijakan menjadi arena tarik menarik yang disebut dengan ranah politik.

Proses pembuatan kebijakan diawali dari masalah yang muncul. Masalah yang dihadapi dapat saja terjadi oleh karena dampak kebijakan yang sudah dibuat, diskrepansi yang terjadi dalam mencapai tujuan yang diinginkan atau oleh adanya isu atau permasalahan yang berkembang di masyarakat. Contoh, masalah yang terjadi akibat dampak kenaikan BBM tahun 2008 yang mengakibatkan daya beli masyarakat makin rendah. Dengan menganalisis permasalahan yang ada disusun formulasi kebijakan, yang dirumuskan dengan melakukan kajian mendalam atau dengan kajian yang sesuai. Oleh karena kebijakan meru- pakan produk publik yang akan diterapkan kepada publik, maka pada tiap proses pembuatan kebijakan dapat saja berlangsung tarik menarik kepentingan diantara pihak-pihak yang berbeda kepentingan.

Tarik menarik yang terjadi diantara pihak yang berkepetingan membuat pengambilan kebijakan tidak terlepas dari proses dan kepentingan politik. Menurut Kreitner(1999: 79), kebijakan dirumuskan sebagai berikut: dalam istilah yang lebih luas, politik adalah suatu seni (sains) tentang pengaruh dan pengawasan publik. Undangundang adalah suatu produk dari proses politik yang membedakan perilaku baik dan buruk. Suatu proses politik yang teratur dipertukan karena masyarakat modern merupakan produk dari kesepakatan diantara perbedaan individu dan kelompok yang sering berbenturan kepentingan dan tujuan. Sekalipun keinginan khusus kelompok terus bertambah tetapi tidak seorang pun dapat memaksakan kehendak. Sistem politik berusaha untuk menyeimbangkan persaingan kepentingan dalam suatu keputusan yang dapat diterima bersama.

\section{Analisis Kebijakan}

Analisis kebijakan bermanfaat untuk mengkaji keterandalan kebijakan dan kepenerimaan kebijakan di masyarakat sebagai solusi terhadap permasalahan yang berkembang. Analisis kebijakan dapat dilaksanakan sebelum atau sesudah kebijakan diterapkan. Suatu analisis dapat dilaksanakan mengantisipasi hasil kebijakan, yang disebut dengan anticipatory atau predictive. Sedangkan penelitian sesudah pelaksanaan kebijakan adalah penelitian retrospective dan evaluatif yang menguraikan dan menterjemahkan kebijakan yang lalu. Dalam hal ini, analisis kebijakan dapat dilaksanakan 
sebagai suatu evaluasi terhadap kebijakan yang telah dilaksanakan.

Analisis kebijakan diharapkan dapat menghasilkan informasi dan argument yang logis mengenai tiga pertanyaan yaitu tentang: 1) nilai yang dicapai saat diujikan, apakah telah memecahkan permasalahan, 2) fakta yang muncul membatasi atau mempercepat pencapaian nilai, dan 3) tindakan pengadopsian yang mungkin menghasilkan informasi ini dan alasan logisnya dapat dilaksanakan dengan tiga pendekatan analisis: empiris, evaluasi dan normatif.

Dalam menganalisis kebijakan terdapat argumen kebijakan dengan 6 elemen, yaitu: 1) policy-relevant information, 2) policy claim, 3) warrani, 4) backing, 5) rebuttal, 6) qualifier. Keenam elemen argumen analisis kebijakan ini merupakan penentu apakah nilai, fakta dan tindakan yang dihasilkan dalam analisis kebijakan terpenuhi sebagai syarat kelayakan suatu hasil analisis kebijakan. Jika saringan keenam elemen argumen kebijakan terhadap nilai, fakta dan tindakan yang diharapkan berhasil dilalui, maka kebijakan atau rekomendasi kebijakan yang dihasilkan layak dilaksanakan.

Metode penelitian yang digunakan dalam analisis kebijakan menurut Dunn adalah analisis kebijakan deskriptif mencakup analisis kebijakan masa lampau (retrospektif) atau evaluasi suatu kebijakan baru yang akan diimplementasikan. Dalam hal ini digunakan metoda retrospektif (apa yang terjadi di masa lampau) dengan pendekatan empiris yang menggambarkan sebab akibat yang diberikan oleh suatu kebijakan publik. Metode deskriptif yang digunakan daiam penelitian ini menyajikan fakta, dan menjelaskan sebab akibat dari suatu kebijakan yang mengarah kepada analisis isi kebijakan (policy content).
Peneliti tidak mengintervensi terhadap isi kebijakan, sehinga analisis yang dilakukan terhadap isi kebijakan pemberdayaan masyarakat yang dianalisis tetapi hanya melaksanakan analisis secara murni dengan menuruti kaidah-kaidah analisis kebijakan yang mengedepankan fakta (pendekatan empiris) dan kriteria (evaluatif) terhadap kebijakan program pemberdayaan masyarakat dan dampaknya terhadap implementasi good governance, dan membuat kesimpulan, serta saran.

\section{Konsep Kebijakan Rencana Tata Ruang Kawasan Pantai Utera Kabupaten Bekasi.}

Kebijakan mengenai Rencana Tata Ruang Kawasan Pantai Utara Kabupaten Bekasi mempunyai tujuan sebagai berikut: "mewujudkan tata ruang kawasan yang berkualitas, serasi dan optimat sesuai dengan kebijaksanaan pembangunan di daerah serta sesuai dengan kebutuhan pembangunan dan kemampuan daya dukung lingkungan. Sasaran Rencana Tata Ruang Kawasan Pantai Utara Kabupaten Bekasi adalah: 1) Terciptanya perkembangan dan pemanfaatan ruang yang terbentuk dari kegiatan perekonomian. 2) Terwujudnya pembangunan yang berkelanjutan sesuai dengan daya dukung lingkungan, 3) Terciptanya perkembangan pembangunan serta terwujudnya pola pemanfaatan ruang secara selaras dan seimbang, 4) Pemberian ijin lokasi terlenggara secara tertib dan tertata baik, dan 5) Sebagai acuan dalam penyusunan rencana lanjutan yang lebih rinci.

Diterbitkannya kebijakan pengelolaan kawasan pesisir dalam yang berupa Peraturan Daerah Nomor: 5 Tahun 2003 tentang Rencana Tata Ruang Kawasan Pantai Utara Kabupaten Bekasi tidak terlepas dari kebutuhan 
untuk program evaluasi kebijakan dan perbaikan kondisi lingkungan-biofisik, kondisi sosial ekonomi, serta kondisi kelembagaan.

\section{METODOLOGI PENELITIAN}

Penelitian ini dilakukan di Wilayah Pesisir Kabupaten Bekasi yang terdiri dari tiga Kecamatan yaitu Kecamatan Babelan, Kecamatan Tarumajaya, dan Kecamatan Muara Gembong yang mencakup wilayah $24.615,06$ ha.

Dalam melakukan evaluasi implementasi kebijakan pengelolaan Kawasan Pantai Utara di Kabupaten Bekasi untuk menganalisis prespsi stakeholder digunakan metode AHP yang merupakan salah satu model untuk pengambilan keputusan yang dapat membantu kerangka berpikir manusia. Metode AHP adalah proses pembentukan skor secara numerik (bobot) agar dapat menyusun rangking dari alternatif-alternatif keputusan atau kriteria yang ada, berdasarkan kesesuaiannya dengan tujuan pengambil keputusan atau penentu kriteria. Adapun proses pembentukan bobot dilakukan melalui pengisian kuesioner AHP, yang disusun untuk menangkap dan mengkuantifikasi persepsi atau penilaian responden atas tingkat kesesuaian masing-masing alternatif atau kriteria dengan tujuan pengambil keputusan, Terkait dengan esensi dari metode AHP tersebut, profil responden yang mengisi kuesioner menjadi elemen penting dalam keseluruhan aplikasi metode AHP. Persepsi atau penilaian yang relevan untuk diperhitungkan dan dilibatkan ke dalam keseluruhan proses AHP adalah persepsi dari individu yang merupakan praktisi atau kalangan ahli di bidang dimana suatu keputusan atau strategi ingin ditentukan.

\section{Proses Pemilihan Kriteria}

Dalam penelitian ini, melalui metode AHP akan dilihat sektor Industri Kecit dan Menengah mana yang paling layak menjadi prioritas untuk dikembangkan. Berdasarkan peraturan perundang undangan dan perda kabupaten bekasi yang berlaku mengenai penggunaan lahan, ada lima prioritas pemanfaatan lahan potensial dikawasan pesisir kabupaten bekasi yaitu: (1) perikanan, (2) pemukiman, (3) industri, (4) pariwisata dan (5) perhubungan. Untuk melihat pemanfaatan lahan mana yang paiing layak diprioritaskan, sudah disusun kriteria-kriteria yang relevan sebagai indikator potensi desa secara

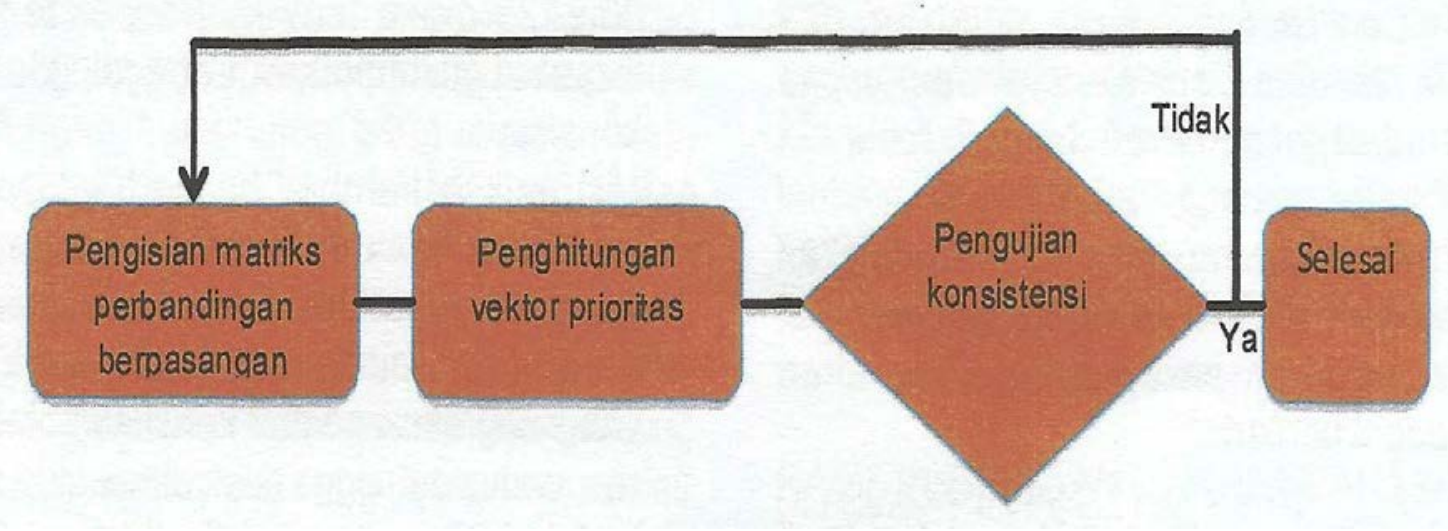

Gambar 3. Tahapan Pengolahan Data Kuesioner AHP 
umum. Adapun penentuan kriteriakriteria tersebut didasarkan pada experts judgment dengan melibatkan pemerintah, swasta, masyarakat, LSM dan bank. Melalui proses diskusi, terpilihlah kriteria-kriteria secara umum dengan mempertimbangkan aspek kepentingan sebagai berikut: a) Peraturan-peraturan yang sudah diterbitkan mengenai pemanfaatan lahan di antaranya untuk kawasan perumahan, b) Perkembangan sosial kependudukan, dan c) Prospek pertumbuhan ekonomi Dari aspekaspek yang dipertimbangkan di atas, maka terpilihlah 8 kriteria yang diaggap mewakili indikator-indikator pemanfaatan lahan yang diperlukan untuk mengembangkan desa atau wilayah Bekasi yang diprioritaskan.

\section{Pengujian Konsistensi}

Konsistensi responden penting sebagai validitas hasil yang akan disimpulkan. Setelah membuat vektor prioritas, tahap selanjutnya adalah menentukan eigen value. Rumus untuk etgen value sebagaimana dibahas oleh Saaty (1980):

$$
C I=\frac{\lambda_{\max ^{-n}}}{n-1} \rightarrow \lambda_{\max }=\text { eigenvalue }
$$

dimana:

$$
\lambda_{\max }=[\text { Total }]_{1 \times 3} *[V P]
$$

Berdasarkan contoh di atas, maka $\lambda_{\max }$ adalah $\left(6.33^{*} 0.19\right)+\left(11^{*} 0.08\right)+$ $\left(1.343^{*} 0.37\right)=3.063$. Kemudian tentukan validitasnya harus memenuhi syarat berikut :

Total matrix apabila : Reject matrix if :

$C R=\frac{C I}{R I}>0.1$

Keterangan :

$\mathrm{CI}=$ Consistency Index
RI = Random Consistency Index (angka didapat dari Prof. Saaty RI table)

$\mathrm{CR}=$ Consistency Ratio

Konsistensi matriks juga disampaikan oleh Alonso \& Lamata (2006) dengan menekankan persyaratan penolakan sebagai berikut :

$$
\lambda_{\max }>n+\alpha(1.7699 n-4.3513)
$$

Keterangan:

$\mathrm{n}=$ dimensi matriks AHP, jumlah criteria yang diperbandingkan

$\alpha=$ tingkat konsistensi yang digunakan (1\%, 5\%, 20\%, 50\%)

\section{Besaran bobot per kriteria yang dihasilkan}

Untuk keperluan analisis dalam penelitian ini, keseluruhan tahapan pengolahanAHP sepertiyang digambarkan pada gambar 2 di atas diterapkan. Terkait dengan metode pengujian konsistensi, tim penyusun menerapkan metode Alonso \& Lamata (2006). Adapun tahapan pengolahan data kuesioner yang dilakukan dalam kajian ini adalah sebagai berikut:

1. Mengisi matriks perbandingan berpasangan untuk masing-masing responden.

2. Menghitung vektor prioritas dan niiai eigenvalue untuk masingmasing matriks.

3. Menguji konsistensi per matriks (per responden) dengan kriteria penolakan eigenvalue maksimal (Amax) Alonso \& Lamata. Dengan menggunakan $\mathrm{a}=50 \%$ dan $\mathrm{n}=20$, maka $A_{\max }=35.5225$;sehingga jika nilai eigenvalue suatu matriks (responden) lebih dari 35.5225 maka matriks (responden) tersebut disimpulkan sebagai tidak konsisten.

4. Memeriksa kembali benar tidaknya pengisian matriks pada responden yang disimpulkan tidak konsisten 
tersebut. Kemudian menolak matriks yang diisi secara tidak konsisten oleh responden sehingga tidakdimasukkan kedalam proses analisis berikutnya.

5. Melakukan agregasi pada keseluruhan matriks yang konsisten.dan menghitung vektor prioritas agregatifnya. Pada tahap ini tidak perlu lagi dilakukan pengujian konsistensi secara agregat karena setiap matriks (yang diagregasi) sudah diuji konsistensinya.

6. Menghasilkan bobot per kriteria yang tidak lain adalah bilanganbilangan di dalam vektor prioritas agregatif.

\section{Teknik Analisis Data}

Analisis terhadap data yang telah diperoleh dari kegiatan pengumpulan data di lapangan, meliputi: 1) Review/ kaji peraturan yang sudah ada dan terkait dengan penggunaan lahan untuk kawasan perumahan, terutama keefektifan atau dampak dari peraturan-peraturan tersebut, diantaranya: peraturan penggunaan lahan, pengaturan teknis; 2) Pengklasifikasian kembali kawasan dan penggunaan lahan \& bangunan; dan 3) Identifikasi luas izin penggunaan lahan untuk kawasan peaimahan di Kabupaten Bekasi, khususnya di kawasan Pantai Utara Kabupaten Bekasi. Sedangkan, tahapan analisis data untuk memperoleh makna yang sesuai dengan perumusan masalah penelitian ini dibagi ke dalam beberapa bagian, antara lain:

\section{a. Analisis Kecenderungan}

Melakukan kajian evaluasi terhadap penggunaan lahan untuk kawasan pesisir dengan melakukan pengumpulan data tentang penggunaan lahan saat ini dan membandingkan guna lahan tersebut dengan Rencana Detail Tata Ruang Wilayah Kabupaten Bekasi. Untuk melihat ketidaksesuaian rencana dengan eksisting pemanfaatan lahan di kawasan pesisir Kabupaten Bekasi digunakan analisis visualisasi di lapangan dengan peta rencana dan masukan dari beberapa stakeholder.

\section{b. Analisis Faktor}

Analisis ini ditujukan nuntuk melihat faktor-faktor yang menjadi penyebab perubahan penggunaan lahan di kawasan pesisir dengan menggunakan metode kausal atau cross chek yang melihat penyebab terjadinya ketidaksesuaiaan penggunaan lahan. Variabel yang akan diteliti dalam mencari penyebab adanya ketidaksesuaian adalah:

1. Perilaku dan motivasi masyarakat kawasan pesisir di dalam pemilihan pemanfaatan lahannya.

2. Kebijaksanaan dari Pemerintah Daerah.

Hasil yang diperoleh dalam analisis seperti dijelaskan di atas, perlu pula dilakukan evaluasi terhadap kebijakan dan dampak yang dilacak dari masukan dan proses kebijakan. Evaluasi formal dilakukan dengan mengacu pada Kebijakan yang sudah dibuat (RTRW Kabupaten Bekasi 2003 - 2013). Dalam evaluasi formal kebijakan ini kriteria evaluatif digunakan berdasarkan pada efektifitas untuk mewujudkan tujuantujuan program kebijakan.

Data yang dikumpulkan, diformulasikan ke dalam bentuk tabel dan peta, sehingga uraian secara deskriptif, dan klasifikasi akan diperoleh gambaran tentang perubahan penggunaan lahan dan ketidaksesuaian rencana tata ruang terhadap penggunaan lahan untuk kawasan pesisir Kabupaten Bekasi. 


\section{HASIL PENELITIAN DAN PEMBA- HASAN}

Analisis Pertama: Kesesuaian Pembangunan di Kawasan Khusus Pantai Utara Kabupaten Bekasi dengan Kebijakan Tentang Rencana Pemanfaatan Ruang

Aspek Perencanaan meliputi Rencana Struktur Ruang Kawasan Pesisir Kabupaten Bekasi, Rencana Pengembangan Transportasi Jalan, dan Rencana Pola Ruang Kawasan Khusus Pantai Utara Kabupaten Bekasi. Sedangkan Kebijakan pola ruang kawasan pesisir Kabupaten Bekasi secara umum meliputi : Rencana Pengembangan Kegiatan, Rencana Pengembangan Agribisnis, Rencana Pengembangan Perdagangan dan Jasa, Rencana Pengembangan Kawasan Industri, Perkantoran, Pergudangan dan Terminal Peti Kemas, serta Rencana Penggunaan Lahan.

Aspek Kesesuaian Realisasi Pembangunan Penggunaan Lahan menyangkut guna lahan di desa-desa pesisirKabupaten Bekasi secara garis besar terdiri dari kawasan pertanian yang terdiri dari pertanian lahan basah, pertanian lahan kering, peternakan dan perikanan, permukiman baik perkotaan maupun pedesaan. Penggunaan lahan permukiman perkotaan dapat didetailkan menjadi perumahan, perdagangan jasa, fasilitas pelayanan, dan pemerintahan.

Analisis Kedua: Pandangan Berbagai Pihak terhadap implementasi Kebijakan Menyangkut Rencana Pola Pemanfaatan Ruang di Kawasan Khusus Pantai Utara Kabupaten Bekasi.

Analisis tentang kendala-kendala dalam rangka implementasi kebijakan menyangkut Rencana Pola Pemanfaatan Ruang di Kawasan Khusus Pantai Utara Kabupaten Bekasi didasarkan kepada pendapat gabungan respoden mengenai pandangan para Stakeholder terhadap prioritas pemanfaatan lahan dalam rangka pengelolaan dan pengembangan kawasan pesisir Kabupaten Bekasi, dapat dijelaskan sebagai berikut:

Tabel 4 Pandangan Pihak Pemerintah terhadap Prioritas Pemanfaatan Lahan Kawasan Pesisir Kabupaten Bekasi

\begin{tabular}{|l|l|l|l|}
\hline No & \multicolumn{2}{|c|}{ Kriteria } & \multicolumn{2}{c|}{$\begin{array}{c}\text { Prioritas Pemanfaatan } \\
\text { Utama }\end{array}$} \\
\hline 1 & $\begin{array}{l}\text { Peningkatan Lapangan } \\
\text { Kerja }\end{array}$ & Perikanan & 0,0164 \\
\hline 2 & Optimasi Pemanfaatan & Industri & 0,0199 \\
\hline 3 & $\begin{array}{l}\text { Peningkatan Pendapatan } \\
\text { Masyarakat }\end{array}$ & Industri & 0,0392 \\
\hline 4 & $\begin{array}{l}\text { Pencegahan Degradasi } \\
\text { Lingkungan }\end{array}$ & Perhubungan & 0,0313 \\
\hline 5 & $\begin{array}{l}\text { Konservasi dan } \\
\text { Rehabilitasi Lingkungan }\end{array}$ & Perhubungan & 0,0277 \\
\hline 6 & Pemerataan Segala Aspek & Perhubungan & 0,0322 \\
\hline 7 & Aktivitas Sosial & Industri & 0,0144 \\
\hline 8 & Tujuan Budaya & Perhubungan & 0,0336 \\
\hline
\end{tabular}

Berdasarkan tabel tersebut dapat dikatakan bahwa jika didasarkan atas kriteria: 1) peningkatan lapangan kerja 2) mencapai optimasi pemanfaatan kawasan pesisir; 3) meningkatkan pendapatan masyarakat pesisir; 4) mencegah degradasi lingkungan pesisir; 5) mencapai tujuan konservasi; 6) mencapai pemerataan disegala aspek; 7) meningkatkan aktivitas sosial kemasyarakatan; dan 8) mencapai tujuan budaya masyarakat pesisir.

Pandangan pemerintah terhadap prioritas utama pemanfaatan adalah sektor industri. Dilihat dari aspek ekonomi, prioritas arahan pengem- 
bangan kawasan Pantura adalah sektor industri. Berbeda dengan kedua aspek lainnya, yaitu; aspek lingkungan dan aspek sosial, prioritas arahan pengembangan memainkan peran sektor perhubungan.

Pandangan para stakeholder swasta terhadap data prioritas pemanfaatan utama kawasan pesisir Kabupaten Bekasi sebagai berikut:

Tabel 5 Pandangan Pihak Swasta terhadap Prioritas Pemanfaatan Lahan Kawasan Pesisir Kabupaten Bekasi

\begin{tabular}{|l|l|l|l|}
\hline No & \multicolumn{1}{|c|}{ Kriteria } & \multicolumn{1}{|c|}{$\begin{array}{c}\text { Prioritas } \\
\text { Pemanfaatan }\end{array}$} & Utama \\
\hline 1 & $\begin{array}{l}\text { Peningkatan Lapangan } \\
\text { Kerja }\end{array}$ & perhubungan & 0,0123 \\
\hline 2 & Optimasi Pemanfaatan & perhubungan & 0,0161 \\
\hline 3 & $\begin{array}{l}\text { Peningkatan Pendapatan } \\
\text { Masyarakat }\end{array}$ & Pariwisata & 0,0157 \\
\hline 4 & $\begin{array}{l}\text { Pencegahan Degradasi } \\
\text { Lingkungan }\end{array}$ & Perikanan & 0,0243 \\
\hline 5 & $\begin{array}{l}\text { Konservasi dan } \\
\text { Rehabilitasi Lingkungan }\end{array}$ & Perikanan & 0,0189 \\
\hline 6 & Pemerataan Segala Aspek & Perikanan & 0,0322 \\
\hline 7 & Aktivitas Sosial & perhubungan & 0,0304 \\
\hline 8 & Tujuan Budaya & Pariwisata & 0,0377 \\
\hline
\end{tabular}

Tabel tersebut menunjukkan bahwa untuk rata rata kriteria, swasta mengutamakan sektor pariwisata. Aspek ekonomi memprioritaskan perhubungan sebagai prioritas permanfaatan, sedangkan aspek lingkungan memprioritaskan sektor perikanan. Sektor pariwisata merupakan prioritas pengembangan kawasan Pantura pada aspek sosial.
Pandangan para stekeholder masyarakat terhadap prioritas pemanfaatan utama desa-desa pesisir Kabupaten Bekasi sebagai berikut:

Tabel Pandangan Pihak Masyarakat terhadap Prioritas Pemanfaatan Lahan Kawasan Pesisir Kabupaten Bekasi

\begin{tabular}{|l|l|l|c|}
\hline No & \multicolumn{1}{|c|}{ Kriteria } & Prioritas & $\begin{array}{c}\text { Peman- } \\
\text { faatan } \\
\text { Utama }\end{array}$ \\
\hline 1 & $\begin{array}{l}\text { Peningkatan Lapangan } \\
\text { Keija. }\end{array}$ & Pemukiman & 0,0259 \\
\hline 2 & Optimasi Pemanfaatan & Industri & 0,0208 \\
\hline 3 & $\begin{array}{l}\text { PeningkatanPendapatan } \\
\text { Masyarakat }\end{array}$ & Pemukiman & 0,0131 \\
\hline 4 & $\begin{array}{l}\text { Pencegahan Degradasi } \\
\text { Lingkungan }\end{array}$ & Pemukiman & 0,0087 \\
\hline 5 & $\begin{array}{l}\text { Konservasi dan } \\
\text { Rehabilitasi Lingkungan }\end{array}$ & Pemukiman & 0,0281 \\
\hline 6 & Pemerataan SegalaAspek & Pemukiman & 0,0092 \\
\hline 7 & Aktivitas Sosial. & Industri & 0,0316 \\
\hline 8 & Tujuan Budaya. & Perikanan & 0,0214 \\
\hline
\end{tabular}

Tabel tersebut memperlihatkan bahwa untuk seluruh kriteria, masyarakat memandang bahwa prioritas pemanfaatan yang diutamakan adatah industri. Untuk aspek ekonomi dan aspek lingkungan memprioritaskan sektor permukiman, sedangkan aspek sosial memprioritaskan sektor industri sebagai prioritas pemanfaatan.

Kriteria peningkatan iapangan kerja, optimasi pemanfaatan dan tujuan pandangan LSM lebih memprioritaskan pariwisata sebagai prioritas pemanfaatan utama guna mengembangkan desa-desa pesisir Kabupaten Bekasi sebagai berikut: 
Tabel 7 Pandangan Pihak LSM terhadap Priorltas Pemanfaatan Lahan Kawasan Pesisir Kabupaten Bekasi

\begin{tabular}{|c|l|l|l|}
\hline No & \multicolumn{1}{|c|}{ Kriteria } & \multicolumn{2}{c|}{$\begin{array}{c}\text { Prioritas Pemanfaatan } \\
\text { Utama }\end{array}$} \\
\hline 1 & $\begin{array}{l}\text { Peningkatan Lapangan } \\
\text { Kerja }\end{array}$ & Pariwisata & 0,0484 \\
\hline 2 & Optimasi Pemanfaatan & Pariwisata & 0,0423 \\
\hline 3 & $\begin{array}{l}\text { Peningkatan Pendapatan } \\
\text { Masyaraka }\end{array}$ & Pariwisata & 0,0129 \\
\hline 4 & $\begin{array}{l}\text { Pencegahan Degradasi } \\
\text { Lingkungan }\end{array}$ & Industri & 0,0129 \\
\hline 5 & $\begin{array}{l}\text { Konservasi Dan } \\
\text { Rehabiiitasi Lingkungan }\end{array}$ & Pariwisata & 0,0335 \\
\hline 6 & Pemerataan Segala Aspek & Perhubungan & 0,0054 \\
\hline 7 & Aktivitas Sosial & Perhubungan & 0,0299 \\
\hline 8 & Tujuan Budaya & Industri & 0,0126 \\
\hline
\end{tabular}

Tabel di atas memperlihatkan bahwa LSM diharapkan dapat meningkatkan peranannya dalam pemberdayaan masyarakat sehingga masyarakat siap untuk terlibat pada sektor pariwisata yang dirasa cukup mampu menjadi faktor pendorong (trigger factor) menuju terciptanya kesejahteraan masyarakat desa-desa pesisir Kabupaten Bekasi.

Sedangkan jika dilihat dari masingmasing aspek, sektor pariwisata dijadikan arahan prioritas pemanfaatan pada aspek ekonomi dan lingkungan. Untuk aspek sosial lebih memprioritaskan pemanfaatan ke sektor perhubungan.

Kalangan perbankan memprioritaskan industri dan perhubungan dalam pengembangan desa pesisir Kabupaten Bekasi. Prirotas tersebut mendukung sektor permodalan dapat dipaparkan dalam tabel berikut:
Tabel 8 Pandangan Pihak Perbankan terhadap Prioritas Pemanfaatan Lahan Kawasan Peslsir Kabupaten Bekasi

\begin{tabular}{|l|l|l|l|}
\hline No & \multicolumn{2}{|c|}{ Kriteria } & \multicolumn{2}{|c|}{$\begin{array}{l}\text { Prioritas Pemanfaatan } \\
\text { Utama }\end{array}$} \\
\hline 1 & $\begin{array}{l}\text { Peningkatan Lapangan } \\
\text { Kerja }\end{array}$ & Pariwisata & 0,0318 \\
\hline 2 & Optimasi Pemanfaatan & Pariwisata & 0,0321 \\
\hline 3 & $\begin{array}{l}\text { Peningkatan Pendapatan } \\
\text { Masyarakat }\end{array}$ & Pariwisata & 0,0072 \\
\hline 4 & $\begin{array}{l}\text { Pencegahan Degradasi } \\
\text { Lingkungan }\end{array}$ & Permukiman & 0,0154 \\
\hline 5 & $\begin{array}{l}\text { Konservasi Dan } \\
\text { Rehabilitasi Lingkungan }\end{array}$ & Pariwisata & 0,0248 \\
\hline 6 & Pemerataan Segala Aspek & Pariwisata & 0,0062 \\
\hline 7 & Aktivitas Sosial & Permukiman & 0,0221 \\
\hline 8 & Tujuan Budaya & Perhubungan & 0,0257 \\
\hline
\end{tabular}

Dalam konteks ini, peranan perbankan lebih ditingkatkan lagi dalam mendukung permodalan bagi pariwisata, karena dengan pariwisata diharapkan kawasan Pantura Kabupaten Bekasi jadi banyak dikenal oleh kalangan luas, berdampak pada masyarakat dan secara otomatis, jika hal ini berhasil tentunya akan meningkatkan perhubungan yang tentunya nanti akan lebih diperhatikan.

Analisis Ketiga: Peningkatan Pendapatan Domestik Bruto dari Implementasi Kebijakan Menyangkut Rencana Pemanfaatan Ruang di Kawasan Khusus Pantai Utara Kabupaten Bekasi

Ekosistem mangrove di Kabupaten Bekasi terdapat di tiga wilayah kecamatan yaitu Kecamatan Babelan, Muara Gembong dan Tarumajaya, 
dengan luas lahan hutan bakau terluasterdapatdi Kecamatan Muara Gembong. Di beberapa lokasi hutan bakau tersebut berada pada kondisi yang kritis, baik disebabkan oleh abrasi pantai maupun adanya penebangan pohon bakau oieh masyarakat.Hasil peninjauan iapangan oleh PKSPL-IPB tahun 2000, dari 2.104,535 ha hutan mangrove, yang mengaiami abrasi seluas 109,567 ha. Kerusakan hutan mangrove juga disebabkan oleh banyaknya penebangan hutan oleh masyarakat untuk dijadikan lahan empang dan pembuatan rumah musiman oleh nelaya.n khususnya sepanjang kali Muara Bendera dengan tidak memperhitungkan dampak yang akan muncul.

Kabupaten Bekasi memiliki garis pantai $72 \mathrm{~km}$, berada di tiga kecamatan di wilayah utara dan membentang dari perbatasan Jakarta sampai perbatasan Karawang. Berdasarkan pengamatan lapangan dan penelusuran data sekunder, kondisi hutan mangrove yang dulu tebal, kini rusak akibat abrasi dan pengambilan manfaat langsung oleh manusia dan kebijakan yang tidak mendukung terhadap lingkungan. Spesies yang dilindungi seperti Lutung Jawa (Trachypitecus auratus) dan Burung Kuntul (Ardeidae) kini menghilang.

Mangrove yang dimiliki Kabupaten Bekasi tersebar di Kecamatan Muara gembong, Babelan dan Tarumajaya. Dari analisis yang dilakukan, luas wilayah hutan bakau dalam kurun waktu 59 tahun (1943 - 2006) telah mengalami penyusutan dan mengalami perubahan secara signifikan, dan luasnya tinggai 16,01 persen dari semula 10.000 hektare menjadi 1.580,05 hektare. Adapun fauna yang sebelumnya berasosiasi dengan hutan bakau di pesisir Kabupaten Bekasi, terdapat 32 jenis, sebagian besar burung rawa seperti kuntul. Juga hewan langka dan dilindungi seperti lutung jawa serta berbagai hewan yang mempunyai potensi ekonomi untuk dibudidayakan, antara lain udang dan kepiting bakau.

Berdasarkan data dari Dinas Pertanian Perkebunan dan Kehutanan, dulu terdapat sekitar 15 ribu hektar hutan mangrove yang terdiri dari 10 ribu hektar lahan yang dimiliki PT Perhutani dan sisanya milik masyarakat. Tetapi, sekarang hutan mangrove yang didominasi jenis bakau milik Perhutani tinggal sekitar 10 hektare. Sedangkan hutan mangrove yang dimiliki rakyat juga mengalami kerusakan. Luas keseluruhan hutan yang saat ini tersisa, tercatat hanya sekitar600 hektare. Banyak faktoryang menjadi penyebab kerusakan hutan mangrove, di antaranya karena faktor alam seperti banjir, juga karena penebangan pohon bakau. Masyarakat di pesisir pada saat awal kerusakan, umumnya memiliki kekhawatiran, jika mangrove tumbuh subur akan membuat masyarakat kehilangan tanah tempat tinggal atau lahan garapan. Selain itu, perilaku masyarakat di tiga wilayah pesisir mengindikasikan ada beberapa pihak yang beralasan, jika membiarkan di pesisir tumbuh hutan mangrove akan mengakibatkan pihak Perhutani mengakui lahan tersebut sehingga mereka tidak dapat lagi tinggal di sana.

Pada tahun 2005 dan 2006, Gerakan Nasional Rehabilitasi Hutan dan Lahan (Gerhan) meremajakan pesisir dengan menanam 729 ribu pohon jenis bakau dan api-api pada lahan 200 hektar di Kecamatan Babelan dan Tarumajaya. Pemerintah Bekasi sendiri, pada tahun yang sama juga melakukan penanaman mangrove dengan volume 75 ribu pohon pada lahan seluas 25 hektare di Kecamatan Muaragembong. Kegiatan 
ini mengalami kegagalan, selain dari ulah masyarakat, terjadi banjir awal Februari 2007. Tanaman yang termasuk kepada kelompok mangrove, umumnya memiliki karakter yaitu baru berakar kuat apabila telah berumur 3-5 tahun sejak penanaman sehingga ketika terjadi banjir, banyak tanaman mangrove yang tercabut lagi. Kabupaten Bekasi merupakan salah satu daerah yang mendapat bantuan dari program Gerhan periode 2003-2008. Secara berturut-turut pada tahun 2003 sampai 2006, daerah ini telah menerima bantuan bibit untuk rehabilitasi di Kecamatan Muara Gembong, Babelan, dan Tarumajaya. Akan tetapi, mulai pada tahun 2006, Dinas Pertanian, Perkebunan dan Kehutanan Kabupaten Bekasi tak lagi menerima program bantuan tersebut. Sebab, saat itu mangrove yang baru ditanam pada program tahun 2005 sudah mengalami kerusakan, sehingga dipertimbangkan untuk tidak menerima bantuan dulu sampai ada pemecahan,

Berdasarkan data Bappeda Kabupaten Bekasi, terdapat 35 kilometer panjang pesisir laut di wilayah ini yang meliputi Kecamatan Muaragembong 22 kilometer, Kecamatan Babelan tiga kilometer, dan Tarumajaya enam kilometer dengan totai luas hutan mangrove 15 ribu hektare, Berdasarkan Rencana Tata RuangWilayah Kabupaten Bekasi 2003-2013, tiga kecamatan pesisir wilayah ini diarahkan untuk hutan lindung dengan ketebalan hutan minimal 500 meter dari bibir pantai.

Sementara, berdasarkan wawancara di lapangan, warga Desa Hurip Jaya, Babelan, Kabupaten Bekasi mengungkapkan, di jarak 500 meter desanya, dulu masih banyak ditumbuhi berbagai jenis mangrove, seperti tanaman bakau. Ketebalan hutan bakau pada 10-15 tahun lalu disebutkan antara 300-400 meter.
Berbeda dengan wilayah lain di kabupaten Bekasi di kawasan Pesisir Kabupaten Bekasi yang menjadi motor penggerak pertumbuhannya adalah sektor pertambangan, ada sembilan titik pertambangan (ekplorasi) minyak milik Pertamina yang berlokasi di kawasan Pesisir Kabupaten Bekasi.

Struktur perekonomian di Kawasan Pesisir Kabupaten Bekasi ditinjau (48,36\%) pada tahun 2009 dari Produk Domestik Regional Bruto (PDRB) didominasi oleh sektor Pertambangan dan Penggalian. Kontribusi terbesar terhadap pembentukan PDRB Kabupaten Bekasi disumbangkan oleh Pertambangan dan Penggalian sebesar Rp. 1,174 triliyun (48,36\%), disusul kemudian oleh sektor perdagangan, hotel, dan restoran sebesar Rp. 589,48 milyar $(24,27 \%)$ dan selanjutnya adalah sektor industri pengolahan sebesar Rp. 218.10 milyar (8,98 \%).

Sedangkan sektor la'mnya yang memberikan kontribusi terhadap PDRB Kawasan Pesisir Kabupaten Bekasi relatif rendah seperti sektor pertanian $(4,34 \%)$; sektor pengangkutan dan komunikasi $(2,48 \%)$; sektor jasa-jasa lainnya $(1,73 \%)$; sektor bangunan dan konstruksi $(3,16 \%)$ dan sektor bank dan lembaga keuangan (0,69\%).

\section{PEMBAHASAN}

\section{Aspek Kebijakan tentang Penge- loaan Wilayah Pesisir dan Pulau- Pulau Kecil}

Dalam satu dekade ini terdapat kecenderungan bahwa Wilayah Pesisir dan Pulau-Pulau Kecil yang rentan mengalami kerusakan akibat aktivitas orang dalam memanfaatkan sumber dayanya atau akibat bencana alam. Selain itu, akumulasi dari berbagai kegiatan eksploitasi yang bersifat parsial/sektoral di Wilayah Pesisir dan 
Pulau-Pulau Kecil atau dampak kegiatan lain di huiu wilayah pesisir yang didukung peraturan perundangundangan yang ada sering menimbulkan kerusakan Sumber Daya Pesisir Pulau Kecil. Peraturan perundang-undangan (Undang-Undang Republik Indonesia No. 27 Tahun 2007 $\mathrm{T}$ entang Pengelolaan Wilayah Pesisir dan Pulau-Pulau Kecil) yang ada lebih berorientasi pada eksploitasi Sumber Daya Pesisir dan Pulau-Pulau Kecil tanpa memperhatikan kelestarian sumber daya. Sementara itu, kesadaran nilai strategis dari pengelolaan wilayah pesisir dan pulau-pulau kecil secara berkelanjutan, terpadu, dan berbasis masyarakat relatif kurang.

Kurang dihargainya hak masyarakat adat/lokal dalam pengelolaan Sumber Daya Pesisirdan Pulau-Putau Kecil seperti sasi, mane'e, panglima laot, awig-awig, terbatasnya ruang untuk partisipasi masyarakat dalam pengelolaan Sumber Daya Pesisir dan Pulau-Pulau Kecii menunjukkan bahwa prinsip pengelolaan pesisirdan pulaupulau kecil terpadu belum terintegrasi dengan kegiatan pembangunan dari berbagai dan daerah. Sistem pengelolaan pesisir tersebut belum mampu mengeliminasi faktor-faktor penyebab kerusakan dan belum memberi kesempatan kepada sumber daya hayati untuk dapat pulih kembali secara alami atau sumber daya nonhayati disubstitusi dengan sumberdaya lain.

Oleh sebab itu, keunikan wilayah pesisirdan pulau-pulau kecil yang rentan berkembangnya konflik dan terbatasnya akses pemanfaatan bagi masyarakat pesisirdan pulau-pulau kecil, perlu dikelola secara baik agar dampak aktivitas manusia dapat dikendalikan dan sebagian wilayah pesisir dipertahankan untuk konservasi.
Masyarakat perlu didorong untuk mengelola wilayah pesisirnya dengan baik-baik dan yang telah berhasil perlu diberi insentif, tetapi yang merusak perlu diberi sanksi. Norma-norma Pengelolaan Wilayah Pesisir dan PulauPulau Kecil tersebut disusun dalam lingkup perencanaan, pemanfaatan, pengelolaan, pengendalian, dan pengawasan, dengan memperhatikan norma-norma yang diatur dalam peraturan perundangundangan lainnya seperti Undang-Undang Nomor26 Tahun 2007 tentang Penataan Ruang (Lembaran Negara Republik Indonesia Tahun 2007 Nomor 68, Tambahan Lembaran Negara Republik Indonesia Nomor4725). Norma-norma Pengelolaan Wilayah Pesisir dan Pulau-pulau Kecil yang akan dimuatdifokuskan pada norma hukum yang belum diatur dalam sistem peraturan perundangundangan yang ada atau bersifat lebih spesifik dari pengaturan umum yang teiah diundangkan. Norma-norma itu akan memberikan peran kepada Pemerintah, masyarakat, dan swasta sebagai pemangku kepentingan baik kepentingan daerah, kepentingan nasional, maupun kepentingan internasional melalui sistem pengelolaan wilayah terpadu. Sesuai dengan hakikat Negara Kesatuan Republik Indonesia sebagai negara hukum, pengembangan sistem Pengelolaan Wilayah Pesisir dan Pulau-Pulau Kecil sebagai bagian dari pembangunan berkelanjutan yang berwawasan lingkungan hidup harus diberi dasar hukum yang jelas, tegas, dan menyeluruh guna menjamin kepastian hukum bagi upaya pengelolaan Wilayah Pesisir dan PulauPulau Kecil. Dasar hukum itu dilandasi oleh Pancasila dan Undang-Undang Dasar Negara Republik Indonesia Tahun 1945. 


\section{Aspek Keruangan}

Undang-Undang ini diberlakukan di Wilayah Pesisir dan Pulau-Pulau Kecil yang meliputi daerah pertemuan antara pengaruh perairan dan daratan, ke arah daratan mencakup wilayah administrasi kecamatan dan ke arah perairan laut sejauh 12 (dua belas) mil laut diukur dari garis pantai ke arah laut lepas dan/atau ke arah perairan Lingkup pengaturan Undang-Undang ini secara garis besar terdiri dari tiga bagian yaitu perencanaan, pengelolaan, serta pengawasan dan pengendalian, dengan uraian sebagai berikut:

\section{a. Perencanaan}

Perencanaan dilakukan melalui pendekatan Pengelolaan Wilayah Pesisir dan Pulau-Pulau Kecil terpadu (Integrated Coastal Management) yang mengintegrasikan berbagai perencanaan yang disusun oleh sektor dan daerah sehingga terjadi keharmonisan dan saling penguatan pemanfaatannya. Pengelolaan Wilayah Pesisir dan PulauPulau Kecil terpadu merupakan pendekatan yang memberikan arah bagi pemanfaatan Sumber Daya Pesisir dan Pulau-Putau Kecil secara berkelanjutan dengan mengintegrasikan berbagai perencanaan pembangunan dari berbagai tingkat pemerintahan, antara ekosistem daratdan laut, serta antara ilmu pengetahuan dan manajemen. Perencanaan Pengelolaan Wilayah Pesisir dan Pulau-Pulau Kecil dilakukan agar dapat mengharmonisasikan kepentingan pembangunan ekonomi dengan pelestarian Sumber Daya Pesisir dan Pulau-Pulau Kecil serta memperhatikan karakteristik dan keunikan wilayah tersebut.

Perencanaan terpadu itu merupakan suatu upaya bertahap dan terprogram untuk memanfaatkan Sumber Daya Pesisir dan Pulau-Pulau Kecil secara optimal agar dapat menghasilkan keuntungan

ekonomi

secara

berkelanjutan untuk kemakmuran masyarakat. Rencana bertahap tersebut disertai dengan upaya pengendalian dampak pembangunan sektorai yang mungkin timbul dan mempertahankan kelestarian sumber dayanya. Perencanaan Wilayah Pesisir dan Pulau-Pulau Kecil dibagi ke dalam empat tahapan: (i) rencana strategis; (ii) rencana zonasi; (iii) rencana pengelolaan; dan (iv) rencanaaksi.

\section{b. Pemanfaatan}

Pengelolaan Wilayah Pesisir dan PulauPulau Kecil mencakup tahapan kebijakan pengaturan sebagai berikut:

1) Pemanfaatan dan pengusahaan perairan pesisir dan pulaupulau kecil dilaksanakan melalui pemberian izin pemanfaatan dan Hak Pengusahaan Perairan Pesisir (HP3). Izin pemanfaatan diberikan sesuai dengan peraturan perundang-undangan dan kewenangan masing-masing instansi terkait.

2) Hak Pengusahaan Perairan Pesisir (HP-3) diberikan di Kawasan perairan budidaya atau zona perairan pemanfaatan umum kecuali yang telah diatur secara tersendiri.

3) Pengaturan Pengelolaan Wilayah Pesisir dan Pulau-Pulau Kecil dimulai dari perencanaan, pemanfaatan, pelaksanaan, pengendalian, pengawasan, pengakuan hak dan pemberdayaan masyarakat, kewenangan, kelembagaan, sampai pencegahan dan penyelesaian konflik.

4) Pengelolaan pulau-pulau kecil dilakukan daiam satu gugus pulau atau kluster dengan memperhatikan keterkaitan ekologi, keterkaitan ekonomi, dan keterkaitan sosial budaya dalam satu bioekoregion dengan pulau induk atau pulau lain sebagai pusat pertumbuhan ekonomi. 
Sumber Daya Pesisirdan Pulau-Pulau Kecil yang relatif kaya sering menjadi pusat pertumbuhan ekonomi dan populasi penduduknya padat. Namun, sebagian besar penduduknya relatif miskin yang memicu tekanan terhadap Sumber Daya Pesisir dan Puiau-Pulau Kecil yang menjadi sumber penghidupannya. Apabila diabaikan, hal itu akan berimplikasi meningkatnya kerusakan Ekosistem pesisir dan putau-pulau kecil.

Selain itu, masih terdapat kecenderungan bahwa industrialisasi dan pembangunan ekonomi di Wilayah Pesisir dan Pulau-Pulau Kecil sering kali memarginalkan penduduk setempat. Oleh sebab itu diperlukan normanorma pemberdayaan masyarakat.

Wilayah Pesisirdan Pulau-Pulau Kecil yang rentan terhadap perubahan perlu dilindungi melalui pengelolaan agar dapat dimanfaatkan untuk memenuhi kebutuhan hidup dan penghidupan masyarakat. Oleh sebab itu, diperlukan kebijakan pengelolaan sehingga dapat menyeimbangkan tingkat pemanfaatan Sumber Daya Pesisir dan Pulau-Pulau Kecil untuk kepentingan ekonomi tanpa mengorbankan kebutuhan generasi yang akan datang melalui pengembangan kawasan konservasi dan sempadan pantai.

\section{c. Pengawasan dan Pengendalian}

Pengawasan dan pengendalian dilakukan untuk:

1. Mengetahui adanya penyimpangan pelaksanaan rencana strategis, rencana zonasi, rencana pengelolaan, serta implikasi penyimpangan tersebut terhadap perubahan kualitas ekosistem pesisir;

2) mendorong agar pemanfaatan sumber daya di Wilayah Pesisir dan Pulau-Pulau Kecil sesuai dengan rencana pengelolaan wilayah pesisirnya;

3) memberikan sanksi terhadap pelanggar, baik berupa sanksi administrasi seperti pembatalan izin atau pencabutan hak, sanksi perdata seperti pengenaan denda atau ganti rugi; maupun sanksi pidana berupa penahanan ataupun kurungan.

4) Undang-Undang tentang Pengelolaan Wilayah Pesisir dan PulauPulau Kecil ini merupakan landasan penyesuaian dengan ketentuan yang tercantum dalam peraturan perundang-undangan yang lain.

Undang-Undang ini mempunyai hubungan saling melengkapi dengan undang-undang lain seperti: undangundang yang mengatur perikanan; undang-undang yang mengatur pemerintahan daerah; undang-undang yang mengatur kehutanan; undang-undang yang mengatur pertambangan umum, minyak, dan gas bumi; undang-undang yang mengatur penataan ruang; undang-undang yang mengatur pengelolaan lingkungan hidup; undangundang yang mengatur pelayaran; undang-undang yang mengatur konservasi sumber daya alam dan ekosistem; undang-undang yang mengatur peraturan dasar pokok agraria; undang-undang yang mengatur perairan; undang-undang yang mengatur kepariwisataan; undang-undang yang mengatur perindustrian dan perdagangan; undang-undang yang mengatur sumber daya air; undang-undang yang mengatur sistem perencanaan pembangunan nasional; dan undang-undang yang mengatur arbitrase dan alternatif penyeiesaian sengketa. UndangUndang ini diharapkan dapat dijadikan sebagai landasan pembangunan wilayah pesisir dan pulau-pulau kecil yang dilaksanakan oleh berbagai sektor terkait. Dengan demikian, dapat 
dihindarkan terjadinya tumpang tindih wewenang dan benturan kepentingan.

\section{KESIMPULAN}

Berdasarkan hasil penelitian mengenai evaiuasi kebijakan pengelolaan Kawasan Pantai Utara Kabupaten Bekasi dapat disimpulkan;

1. Pengembangan ruang menggunakan konsep linier untuk kegiatan perdagangan, konsep pengelompokan kawasan, dan konsep menetapkan pusat-pusat kawasan.

2. Pandangan para stake holder yang terdiri dari Pemerintah, LSM, Masyarakat, Swasta, Perbankan, meprioritaskan pemanfaatan dalam pengelolaan dan pengembangan kawasan pantai utara Kabupaten Bekasi untuk aspek ekonomi dan aspek lingkungan ke arah sektor pariwisata, sedangkan aspek sosial menintik beratkan ke sektor perhubungan.

3. Dampak positif implementasi kebijakan tentang rencana pemanfaatan ruang di Kawasan Pantai Utara Kabupaten Bekasi bagi pengingkatan pendapatan domestik bruto berdasarkan kontribusi yang terbesar dengan urutan; sektor pertambangandanpenggalian; sektor perdagangan; hotel dan restoran; sektor industri pengolahan; sektor pertanian; sektor pengangkutan dan komunikasi; sektor jasa-jasa lainnya; sektor bangunan dan konstruksi; dan sektor bank dan lembaga keuangan.

\section{REKOMENDASI}

1. Dalam perencanaan dan pemanfaatan ruang Kawasan Pantai Utara Kabupaten Bekasi, Pemerintah Daerah harus menyesuai dengan amanat UU. No. 26 Tahun 2007
Tentang Penataan Ruang dan UU No.27 Tahun 2007 Tentang Pengelolaan Wilayah Pesisir dan Pulau-Pulau Kecil.

4. Pemerintah Daerah Kabupaten Bekasi harus melibatkan stake holder dalam kegitan pengelolaan sumber daya pesisir.

5. Dibutuhkan suatu regulasi yang sifatnya tegas dan mengikat untuk melindungi ekosistem mangrove di kawasan pesisir.

6. Dioerkukan suatu kegiatan pengendalian dan pengawasan agar sesuai dengan tujuan yang diamanatkan Perda No.5 Tahun 2003 tentang Rencana Tata Ruang Kawasan Khusus Pantai Utara Kabupaten Bekasi 2003-2013.

7. Pemerintah Daerah Kabupaten Bekasi dalam membuat kebijakan pengeioiaan kawasan pantai utara hendaknya lebih mendengarkan aspirasi masyarakat pesisir agar kebijakan tersebut mendapat dukungan.

8. Peraturan Daerah No.5 Tahun 2003 tentang Rencana Tata Ruang Kawasan Khusus Pantai Utara Kabupaten Bekasi 2003-2013 akan berakhir, sehingga pemerintah Kabupaten Bekasi perlu mengadakan kajian akademis untuk penyempurnaan Perda di masa mendatang.

9. Melakukan penelitian lanjutan dengan memperdalam evaluasi kebijakan yang menyeluruh dari setiap sektor, sehingga akan menghasilkan kebijakan yang tepat dalam proses pembangunan wilayah pesisir yang berkelanjutan. 


\section{DAFTAR PUSTAKA}

1. Alonso.J. dan T. Lamata, Consistency in the Analytic Hierarchy Process: a New Approach. International Journal of Uncertaint, Fuzzines, and KnowledgeBased System Vol.14 No.4: Spanyol, 2006

2. Anon. From Crisis To Sustainability. Paving the Way for Sustainability Development in Indonesia. Overview of the implementation of agenda 21 : Jakarta Ministry of Environment Republic Indonesia, 2002.

3. Doxiadis, Perumahan dan Pemukiman di Indonesia, Institut Teknologi Bandung,: Bandung, 2005.

4. Clark, J. R., Coastal Zone Management: Handbook, Lewis Publishers, Boca Raton : NewYork, 1996

5. Dahuri, R., Rais, J.M., Ginting S.P. dan Sitepu, M.J., Pengelolaan Sumberdaya Wilayah Pesisirdan Lautan Secara Terpadu. Pradnya Paramita: Jakarta, 2004.

6. __ Reposisi Pembangunan Kelautan

Sebagai Implikasi Pelaksanaan Otonomi Daerah Dalam Menyongsong Milenium Ke-3. Makalah, disampaikan dalam kegiatan Lembaga llmu Pengetahuan Indonesia: Jakarta, 1999.

7. Departemen Kelautan dan Perikanan R.I., Keputusan Menteri Kelautan dan Perikanan No.: Kep. 10/Men/2002 Tentang Pedoman Umum Perencanaan Pengelolaan Pesisir Terpadu: Jakarta, 2002.

8. Eko Budihardjo, Tata Ruang Perkotaan, Alumni: Bandung, 1996.

9. Eugene P. Odum, Dasar-dasar Ekologi, terjemahan Tjahyono S, Gajah Mada University Press : Yogyakarta, 1993.

10. Haryoguritno, Sri I. R., StandarDan Kriteria Sungai Yang Berkelanjutan Serta Sistem Penunjang Pengambilan Keputusan Untuk Pengelolaannya (Kasus Asia Tenggara Dan Pasifik). IPB: Bogor,1998.
11. Naskah Akademik Pengelolaan Wilayah Pesisir, Departemen Kelautan dan Perikanan Republik Indonesia : Jakarta, 2000.

12. Odum, Eugene P. Dasar-dasar Ekologi, terjemahan Tjahyono S, Gajah Mada University Press : Yogyakarta, 1971.

13. Paul R. Ehrlich, A.H. Ehrlich and J.P. Holdren. Ecoscience. Population, Resources, Environment, Sanfransisco: W.H. Freeman and Co : San Fransisco, 1997.

14. Supriyono, dkk, Sistem Pemilihan Pejabat Struktural dengan Metode AHP. Seminar Nasional III SDM Teknologi Nuklir STTN BATAN : Jakarta, 2007.

15. Susilo, S.B, Perencanaan Perikanan Nasional dengan Pendekatan Model dan Simulasi. J. II. Pert. Indo: Jakarta,1999.

16. Tjuk Kuswartojo, Perumahan dan Permukiman di Indonesia, Institut Teknologi Bandung : Bandung, 2005.

17. William P. Cunningham, Environmental Science, Margaret J.Kemp: New York, 2005.

18. Wadi D. Haddad dan Terri Demsky, The Dinamics of Education Policy making: Case Studies of Burkina Faso, Jordan, Peru, dan Thailand : Washington, DC, The World Bank,1994.

19. Undang-Undang No. 26 Tahun 2007, tentang Penataan Ruang, pasal 28

20. Undang-Undang No. 32 Tahun 2009 Tentang Perlindungan dan Pengelolaan Lingkungan Hidup., pasal 3

21. Undang-Undang No. 5 Tahun 1960 tentang Peraturan dasar pokok agraria

22. Undang-Undang No. 32 Tahun 2004 Tentang Pemerintahan Daerah 